\title{
Aspek yang mempengaruhi keputusan pembelian dan kepuasan pelanggan pada Rumah Makan Hasrat
}

\author{
Yulianda Sari \\ Prodi Ilmu Administrasi Niaga, STIA Lancang Kuning Dumai \\ E-mail. korespondesi : ythalinaathayandasari@gmail.com
}

\begin{abstract}
In running a restaurant business, it must have its own tendency to make it look different from its competitors. Rumah Makan Hasrat is recognized as a restaurant that serves Malaya specialties and has to consider different aspects in order to maintain customer satisfaction. High prices, inadequate building forms, and insufficient consumer facilities are the main issues in this study. The aim of this study is therefore to examine the aspects that affect purchase decisions and customer satisfaction at the Desire Restaurant. The study was undertaken using path analysis. There had been 100 respondents involved. The results obtained were all constructs had a significant effect on purchasing decisions and customer satisfaction. The author suggests that, in order to enhance service to customers or consumers, Rumah Makan hasrat should pay attention to the complaints and inputs submitted by customers and resolve them immediately.
\end{abstract}

Keywords: Purchase decision, Customer satisfaction, Restaurant

\begin{abstract}
Abstrak
Dalam menjalankan bisnis rumah makan tentunya dituntut untuk memiliki cara tersendiri agar terlihat berbeda dari pesaingnya. Rumah makan Hasrat dikenal sebagai rumah makan yang menyajikan masakan khas melayu harus mempertimbangkan berbagai aspek guna menjaga kepuasan pelanggan. Tingginya harga, belum memadainya bentuk bangunan dan masih belum tercukupinya tempat dalam menampung pelanggan tentunya menjadi isu utama dalam penelitian ini. Oleh karena itu, tujuan dari penelutuan ini adalah untuk melihat aspek yang mempengaruhi keputusan pembelian dan kepuasan pelanggan di Rumah Makan Hasrat. Analisis yang dilakukan dengan menggunakan analisis jalur (path analysis). 100 orang konsumen dijadikan responden. Hasil penelitian diperoleh yaitu semua konstruk berpengaruh signifikan terhadap keputusan pembelian dan kepuasan pelanggan. Saran yang dapat diberikan yaitu dalam meningkatkan pelayanan terhadap pelanggan atau konsumen, sebaiknya pihak Rumah Makan Hasrat di Rokan Hilir memperhatikan keluhan dan masukan yang disampaikan oleh pelanggan dan segera mengatasinya.
\end{abstract}

\section{Kata kunci : Keputusan pembelian , Kepuasan pelanggan, Rumah makan}

\section{PENDAHULUAN}

Dalam sebuah bisnis, pelaku usaha diharapkan memeiliki kepekaan terhadap sebuah perubahan dan memposisikan kepuasan pelanggan sebagai tujuan utama. Kepuasan pelanggan merupakan rasa senang dan rasa kecewa yang dirasakan konsumen yang timbul setelah mengetahui hasil kerja dengan hasil yang didapatkan (Badriyah et al., 2020). Apabila konsumen merasa puas, maka akan timbul rasa setia dan menilai baik terhadap perusahaan yang memberikan layanan (Efendi, 2020).

Tidak terkecuali dalam sebuah usaha kuliner baik berupa usaha makanan dan minuman dimulai dari bersekala kecil, menengah hingga skala atas. Pelaku usaha ini sering dikenal dengan bisnis food service. Dalam bisnisnya dituntut untuk memiliki cara 
tersendiri agar terlihat berbeda dari kompetiternya. Hal ini sesuai dengan pendapat (Rahman et al., 2020) dimana mengatakan bahwa dalam melakukan sebuah bisnis haruslah mempunyai sebuat strategi yang membuat konsumen senang dan memiliki pengalaman yang tak terlupakan setelah berkunjung. Hal ini penting, dimana saat ini timbul sebuah budaya baru dimana seiring tingginya mobilitas masyarakat dan sibuknya kegiatan rutin dan berbagai aktifitas yag mengakibatkan pola mencari makan dan minuman secara praktis. Hal ini tentunya disambut baik oleh pelaku usaha yang sebenarnya melihat sebuah peluang bisnis yang menjanjikan. Dimana pelaku usaha harus merubah sudut pandang dalam melihat bisnis food service ini yang dahulu hanya menyediakan makanan kini menjadi sebuah tempat dimana para pelanggan juga dapat menikmati layanan disamping layanan makanan yang diberikan.

Tempat usaha food service yang memiliki design interior yang modern saat ini telah banyak diminati. Hiburan tambahan yang disediakan juga menambah kenyamanan bagi pelanggannya. Ketersediaan music live, free wifi serta tempat yang modern mempengaruhi keputusan pembelian konsumen. Keputusan pembelian merupakan Langkah yang dibuat karena seseorang merasa tertarik terhadap produk sehingga akan mencobanya dan membelinya (Andika \& Susanti, 2018). Rahman et al (2020) yang mengatakan bahwa kafe, restoran atau rumah makan saat ini dialih fungsikan sebagai tempat berkumpulnya orang yang memanfaatkan fasillitasnya sebagai pendukung dalam kegiatannya. Seperti melakukan pertemuan dalam kepentingan bisnis, arisan dan lainlain.

Meluasnya bisnis food service ini juga terjadi di Kabupaten Rokan Hilir Provinsi Riau. Keadaan ini tentunya menambah semangat bagi para pelaku usaha untuk dapat berpartisipasi dan berlomba-lomba dalam memberikan layanan terbaik. Rumah Makan "Hasrat" misalkan, merupakan rumah makan yang legendaris di Rokan Hilir. Berdasarkan observasi awal yang penulis lakukan, Sebagai restoran yang terkenal, letaknya sangat strategis dimana terletak dijalan lintas yang cukup strategis. Setiawan et al (2020) mengatakan dalam melakukan bisnis, lokasi menjadi hal yang penting untuk diperhatikan, dimana memperhatikan lokasi dan menentukan sebuah lokasi yang benarbenar tepat menjadi point sebuah bisnis akan maju. Sedangkan Aryandi \& Onsardi (2020) mengatakan bahwa lokasi memiliki pengaruh yang positif dan signifikan terhadap pembelian dimana lokasi yang baik cenderung menaikkan keputusan dalam membeli.

Berbagai menu unggulan yang terkenal seperti gulai udang, ikan asam pedas baung, sambal terasi, pangek, gulai rebung, rendang, ikan dan ayam bakar, serta dendeng daging juga tersedia disini. Dengan memulai bisnisnya pada pukul 06.00 WIB hingga 22.00 WIB, rumah makan Hasrat ini memilliki pengunjung yang semakin tahun bertambah.

Tabel 1. Pembelian Pada Tahun 2015-2019

\begin{tabular}{ccc}
\hline Bulan & Jumlah Pelanggan & Persentase \\
\hline 2015 & 3.126 & $16 \%$ \\
2016 & 2.547 & $14 \%$ \\
2017 & 4.954 & $26 \%$ \\
2018 & 2.065 & $11 \%$ \\
2019 & 6.350 & $34 \%$ \\
\hline
\end{tabular}

Sumber: Rumah makan hasrat, 2020(diolah)

Dari Tabel 1 terlihat bahwa dari tahun ke tahun jumlah pelanggan semakin meningkat. Hal ini terlihat bahwa adanya kepuasan pelanggan, peningkatan produk serta peningkatan layanan yang menyebabkan kepuasan pelanggan sehingga dapat terciptalah loyalitas pada pelanggan rumah makan tersebut.

Harga juga merupakan variabel yang juga penting untuk diperhatikan. Harga adalah sebuah faktor penentu konsumen untuk menentukan pembelian barang dan jasa (Zuliarni 
\& Hidayat, 2013). Tingkat harga mencerminkan sebuah kualitas dari produk dan pelayanan yang mempengaruhi konsumen untuk memilih keinginannya untuk berbelanja (Rasmikayati et al., 2020; Rahman et al., 2020). Adapun jenis dan harga produk makanan pada Rumah Makan Hasrat dapat dijelaskan pada tabel berikut:

Tabel 2. Jenis dan harga produk makanan

\begin{tabular}{clc}
\hline No & \multicolumn{1}{c}{ Menu Makanan } & Harga \\
\hline 1. & Gulai Udang/Sambal Udang & Rp. $50.000-70.000$ \\
2. & Ikan Asam Pedas Baung 30.000 \\
3. & Pangkek & Rp. 15.000 \\
4. & Gulai Rebung & Rp. 15.000 \\
5. & Rendang Daging dan Ayam & Rp. 25.000 \\
6. & Ikan dan Ayam Bakar & Rp. $10.000-15.000$ \\
7. & Dendeng Daging & Rp. 25.000 \\
8. & Telur Gulai & Rp. 10.000 \\
9. & Cincang Daging & Rp. 25.000 \\
10. & Gulai Ikan Salai/Sambal Ikan Salai & Rp. 30.000
\end{tabular}

Sumber: Rumah makan hasrat, 2020(diolah)

Dari Tabel 2 terlihat bahwa harga yang ditawarkan disetiap item yang dijual baik lauk dan pauk yang disediakan relatif tinggi dibandingkan dengan rumah makan yang ada disekitarnya yang juga sama. Hal ini dianggap wajar, karena tingginya harga bahan pokok saat penelitian ini dilakukan juga menjadi alasan dari pihak Rumah Makan untuk menetapkan harga. Produk yang ditawarkan tentunya menjadi hal yang utama untuk dipertahankan, mengingat restoran ini merupakan restoran khas melayu, dimana menawarkan produknya yang berkualitas dan citra rasa yang lezat dan nikmat yang tentunya mendapat rasa tersendiri dilidah pelanggannya. Hal ini selaras dengan pendapat Rasmikayati et al (2020) mengatakan Kualitas produk menjadi elemen penting dalam melihat tingkat kepuasan dari konsumen. Kotler dan Armstrong dalam Nuristiqomah et al (2020) mendefinisikan bahwa kualitas produk merupakan sebuah kualitas hasil kerja dari produk berkemampuan melaksanakan fungsinya

Namun dalam tingginya pelanggan serta tingginya harga yang ditawarkan, juga masih ada keluhan dari konsumen yang berkaitan dengan bentuk bangunan dan tempat duduk yang disediakan masih belum memadai. Hal ini penting menginggat jumlah pelanggan yang dimiliki cukup banyak, terlebih pada jam makan siang. Adanya antrian bagi pelanggan untuk dapat menikmati produk dan antrian pelanggan untuk duduk dan makan juga menjadi pemandangan setiap harinya. Hal ini tentunya berkaitan dengan kualitas layanan yang diberikan oleh Rumah makan Hasrat. Pada prinsipnya, pelayanan yang berkualitas merupakan keinginan dari penerima pelayanan (Afrizal, 2020; Afrizal \& Sahuri, 2012). Sementara Bakti et al (2020) mengatakan bahwa kualitas pelayanan membandingkan tingkat layanan dengan ekspektasi pelanggan sehingga kualitas layanan di lakukan dengan pemenuhan kebutuhan dan keinginan konsumen (Andika \& Susanti, 2018). Aryandi \& Onsardi (2020) juga mengatakan bahwa kualitas pelayanan mempunyai pengaruh positif dan signifikan terhadap keputusan pembelian, apabila kualitas pelayanan yang diberikan baik, maka keputusan pembelian akan tinggi.

dari uraian diatas, maka penulis menetapkan tujuan penelitian yaitu untuk megetahui aspek yang mempengaruhi keputusan pembelian dan kepuasan pelanggan pada rumah makan hasrat di Rokan Hilir Provinsi Riau.

\section{METODE}

Penelitian menggunaan Metode deskriptif kuantitatif. Teknik pengambilan sampel dalam penelitian ini menggunakan Probability Sampling (Jonathan, 2006) ditetapkan 100 orang sampel yaitu konsumen tetap dan sudah beberapa kali membeli. Kuesioner 
terstruktur yang telah dibuat dan disebarkan ke responden dan data skunder berupa data pendukung dari Lokasi penelitian. Analisis data menggunakan analisis jalur (path analysis) skematik diagram sub struktur dua yang dapat melihat pola hubungan setiap variable dan mengetahui pengaruh yang ada baik itu langsung maupun tidak langsung dari variable bebass dan terikatnya. (Shafinah \& Ahmad, 2018).

\section{HASIL DAN PEMBAHASAN}

Hasil analisis jalur untuk pengaruh harga, lokasi, kualitas produk dan kualitas pelayanan terhadap keputusan pembelian dan kepuasan pelanggan pada Rumah Makan Hasrat di Rokan Hilir Riau dapat dilihat pada uraian berikut:

\section{Pengaruh harga terhadap keputusan pembelian}

Harga terhadap keputusan pembelian yang ditunjukkan oleh niai $\mathrm{R}$ sebesar 0,789 dan e1 0.459, yang berarti koefisien korelasinya sedang, ini menunjukkan arah hubungan berbanding lurus, artinya harga berpengaruh terhadap keputusan pembelian.

Tabel 3. Hasil analisa hipotesis 1

\begin{tabular}{cccc}
\hline Pengaruh & R & e1 & Kes \\
\hline Harga :Keputusan pembelian & 0.789 & 0.459 & sedang \\
\hline
\end{tabular}

Sumber: Data diolah, 2020

\section{Pengaruh lokasi terhadap keputusan pembelian}

Lokasi terhadap keputusan pembelian yang dltunjukkan oleh niai $\mathrm{R}$ sebesar 0,658 dan e1 0.582, yang berarti koefisien korelasinya sedang ini menunjukkan arah hubungan berbanding lurus, artinya lokasi berpengaruh terhadap keputusan pembelian.

Tabel 4. Hasil analisa hipotesis 2

\begin{tabular}{lccl}
\hline Pengaruh & R & e1 & Kes \\
\hline $\begin{array}{l}\text { Lokasi : } \\
\text { Keputusan pembelian }\end{array}$ & 0.658 & 0.582 & Sedang \\
\hline
\end{tabular}

Sumber: Data diolah, 2020

\section{Pengaruh kualitas produk terhadap keputusan pembelian}

Kualitas produk terhadap keputusan pembelian yang dltunjukkan oleh niiai R sebesar 0,032 dan e1 0.983 , yang berarti koefisien korelasinya sangat kuat ini menunjukkan arah hubungan berbanding lurus, artinya kualitas produk mempunyai pengaruh terhadap keputusan pembelian.

Tabel 5. Hasil Analisa Hipotesis 3

\begin{tabular}{lccc}
\hline \multicolumn{1}{c}{ Pengaruh } & R & e1 & Ket \\
\hline $\begin{array}{l}\text { Kualitas produk: } \\
\text { Keputusan pembelian }\end{array}$ & 0.032 & 0.983 & Sangat kuat \\
\hline
\end{tabular}

Sumber: Data diolah, 2020

\section{Pengaruh kualitas pelayanan terhadap keputusan pembelian}

Hubungan Kualitas pelayanan dan keputusan pembelian yang ditunjukkan oleh niiai $\mathrm{R}$ sebesar 0,900 dan e1 0.316 yang berarti koefisien korelasinya rendah ini menunjukkan arah hubungan berbanding lurus, artinya kualitas pelayanan berpengaruh terhadap keputusan pembelian. 
Tabel 6. Hasil Analisa Hipotesis 4

\begin{tabular}{cccc}
\hline Pengaruh & R & e1 & Ket \\
\hline $\begin{array}{l}\text { Kualitas pelayanan: } \\
\text { Keputusan pembelian }\end{array}$ & 0.900 & 0.316 & rendah \\
\hline
\end{tabular}

Sumber: Data diolah, 2020

\section{Pengaruh harga terhadap kepuasan konsumen}

Harga terhadap kepuasan pelanggan yang dltunjukkan oleh niai R sebesar 0,777 dan e1 0.472, yang berarti koefisien korelasinya sedang, ini menunjukkan arah hubungan berbanding lurus, artinya harga berpengaruh terhadap kepuasan pelanggan.

Tabel 7. Hasil Analisa Hipotesis 5

\begin{tabular}{lccc}
\multicolumn{1}{c}{ Pengaruh } & R & e1 & Ket \\
\hline $\begin{array}{l}\text { Harga: } \\
\text { Kepuasan pelanggan }\end{array}$ & 0.777 & 0.472 & sedang \\
\hline
\end{tabular}

Sumber: Data diolah, 2020

\section{Pengaruh lokasi terhadap kepuasan konsumen}

Lokasi terhadap kepuasan pelanggan ditunjukkan oleh niai R sebesar 0,562 dan e1 0.749 , yang berarti koefisien korelasinya kuati menunjukkan arah hubungan berbanding lurus, artinya lokasi berpengaruh terhadap kepuasan pelanggan.

Tabel 8. Hasil Analisa Hipotesis 6

\begin{tabular}{lccc}
\hline \multicolumn{1}{c}{ Pengaruh } & R & e1 & Ket \\
\hline $\begin{array}{l}\text { Lokasi : } \\
\text { Kepuasan pelanggan }\end{array}$ & 0.562 & 0.749 & Kuat \\
\hline
\end{tabular}

Sumber: Data diolah, 2020

\section{Pengaruh kualitas produk terhadap kepuasan konsumen}

Kualitas produk terhadap kepuasan pelanggan ditunjukkan oleh niiai R sebesar 0,032 dan e1 0.983, yang berarti koefisien korelasinya sangat kuat ini menunjukkan arah hubungan berbanding lurus, artinya kualitas produk berpengaruh terhadap kepuasan pelanggan.

Tabel 9. Hasil Analisa Hipotesis 7

\begin{tabular}{cccc}
\hline \multicolumn{1}{c}{ Pengaruh } & R & e1 & Ket \\
\hline $\begin{array}{l}\text { Kualitas produk : } \\
\text { Kepuasan pelanggan }\end{array}$ & 0.032 & 0.983 & Sangat kuat \\
\hline
\end{tabular}

Sumber: Data diolah, 2020

\section{Pengaruh kualitas pelayanan terhadap kepuasan konsumen}

Kualitas pelayanan terhadap kepuasan pelanggan ditunjukkan oleh niai $\mathrm{R}$ sebesar 0,763 dan e1 0.486 yang berarti koefisien korelasinya sedang ini menunjukkan arah hubungan berbanding lurus, artinya kualitas pelayanan berpengaruh terhadap kepuasan pelanggan. 
Tabel 10. Hasil analisa hipotesis 8

\begin{tabular}{cccc}
\hline Pengaruh & R & e1 & Ket \\
\hline $\begin{array}{c}\text { Kualitas pelayanan : } \\
\text { Kepuasan pelanggan }\end{array}$ & 0.763 & 0.486 & sedang \\
\hline Sumber : Data Penelitian (2020) & & &
\end{tabular}

Sumber : Data Penelitian (2020)

Pengaruh harga, lokasi, kualitas produk dan kualitas pelayanan terhadap keputusan pembelian

Dari analisis yang dilakukan diperoleh hasil sebagai berikut:

Tabel 11. Hasil analisa hipotesis 9

\begin{tabular}{lccc}
\multicolumn{1}{c}{ Pengaruh } & R & e1 & Ket \\
\hline $\begin{array}{l}\text { Harga : } \\
\text { Keputusan pembelian } \\
\text { Lokasi : }\end{array}$ & 0.789 & 0.459 & Sedang \\
$\begin{array}{l}\text { Keputusan pembelian } \\
\text { Kualitas Produk : } \\
\text { Keputusan pembelian }\end{array}$ & 0.658 & 0.582 & Sedang \\
$\begin{array}{l}\text { Kualitas pelayanan : } \\
\text { Keputusan pembelian }\end{array}$ & 0.032 & 0.983 & Sangat Kuat \\
\hline $\begin{array}{l}\text { Sumber: Data diolah, } 2020 \\
\quad\end{array}$ & 0.900 & 0.316 & Rendah \\
\hline
\end{tabular}

Terlihat bahwa hubungan variabel eksogennya yaitu harga, lokasi, kualitas produk serta kualitas pelayanan mempunyai pengaruh langsung terhadap variabel endogennya yaitu keputusan pembelian.

\section{Pengaruh harga, lokasi, kualitas produk dan kualitas pelayanan terhadap kepuasan pelanggan}

Dari penelitian yang dilakukan diperoleh hasil sebagai berikut:

Tabel 12. Hasil analisa hipotesis 10

\begin{tabular}{lccc} 
& Pengaruh & e1 & Ket \\
\hline $\begin{array}{l}\text { Harga : } \\
\text { Kepuasan pelanggan }\end{array}$ & 0.777 & 0.472 & Sedang \\
$\begin{array}{l}\text { Lokasi : } \\
\text { Kepuasan pelanggan }\end{array}$ & 0.562 & 0.749 & Kuat \\
$\begin{array}{l}\text { Kualitas Produk: } \\
\text { Kepuasan pelanggan }\end{array}$ & 0.032 & 0.983 & Sangat Kuat \\
$\begin{array}{l}\text { Kualitas pelayanan : } \\
\text { Kepuasan pelanggan }\end{array}$ & 0.763 & 0.486 & Sedang \\
\hline $\begin{array}{l}\text { Sumber: Data diolah, } 2020 \\
\text { Kumberat }\end{array}$ & & &
\end{tabular}

Data di atas menunjukkan bahwa hubungan antara variabel eksogen harga, lokasi, kualitas produk dan kualitas pelayanan mempunyai pengaruh langsung terhadap variabel endogen kepuasan pelanggan. 


\section{Pengaruh keputusan pembelian terhadap kepuasan pelanggan}

Hasil analisis jalur pengaruh langsung keputusan pembelian terhadap kepuasan pelanggan yaitu dilihat melalui persamaan:

Tabel 13. Hasil analisa hipotesis 11

\begin{tabular}{cccl}
\hline Pengaruh & R & e1 & Ket \\
\hline $\begin{array}{l}\text { Keputusan pembelian: } \\
\text { Kepuasan pelanggan }\end{array}$ & 0.866 & 0.605 & sedang \\
\hline
\end{tabular}

Sumber: Data diolah, 2020

Keputusan pembelian terhadap kepuasan pelanggan yang dltunjukkan oleh nilai $\mathrm{R}$ sebesar 0,866 dan e1 0.605 yang berarti koefisien korelasinya sedang ini menunjukkan arah hubungan berbanding lurus, artinya keputusan pembelian berpengaruh terhadap kepuasan pelanggan. Hasil analisis jalur untuk pengaruh harga (X1), lokasi (X2), kualitas produk (X3) dan kualitas pelayanan (X4) terhadap keputusan pembelian (Y) dan kepuasan pelanggan (Z) tampak pada gambar 1.

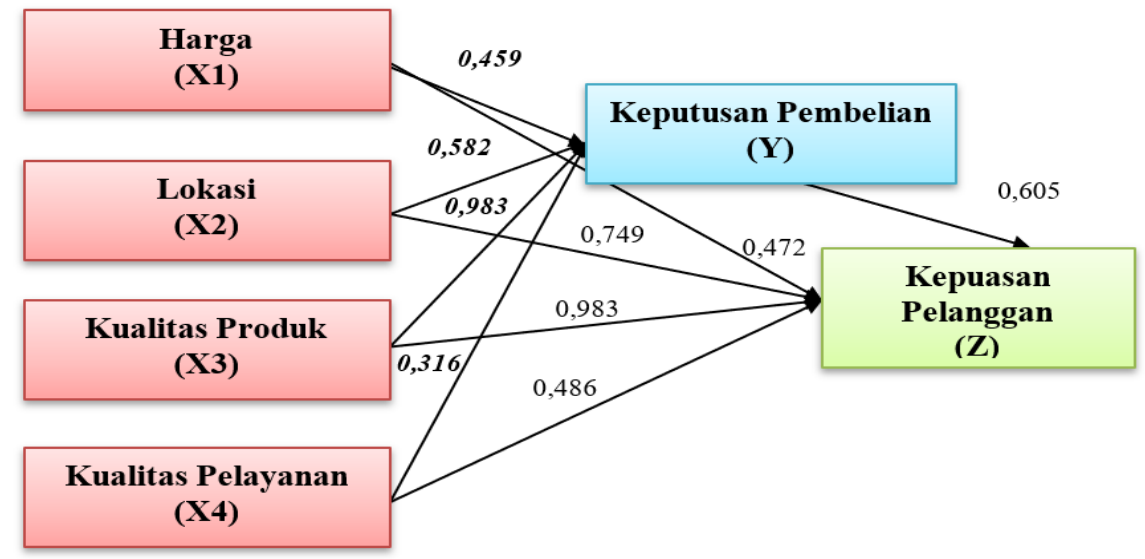

Gambar 1. Model Jalur (Path) Analysis)

\section{KESIMPULAN DAN SARAN}

\section{Kesimpulan}

Berdasarkan hasil penelitian diperoleh kesimpulan bahwa 1). Harga berpengaruh terhadap keputusan pembelian, 2). Lokasi juga berpengaruh terhadap keputusan pembelian, 3).Kualitas produk berpengaruh terhadap keputusan pembelian, 4). Kualitas pelayanan berpengaruh terhadap keputusan pembelinuran, 5). Sedangkan harga juga berpengaruh terhadap kepuasan pelanggan, (6). Lokasi berpengaruh terhadap kepuasan pelanggan, (7). Kualitas produk berpengaruh terhadap kepuasan pelanggan, (8). Kualitas pelayanan berpengaruh terhadap kepuasan pelanggan dan sedangkan (9). Hubungan antara variabel konstruk eksogen mempunyai pengaruh langsung terhadap variabel endogen, (10) Hubungan antara variabel eksogen mempunyai pengaruh langsung terhadap variabel endogen (11). Variabel keputusan pembelian berpengaruh terhadap kepuasan pelanggan pada Rumah Makan Hasrat di Rokan Hilir Riau.

\section{Saran}

Penulis menyarankan bahwa dalam meningkatkan pelayanan sebaiknya pihak rumah makan hasrat di Rokan Hilir Riau memperhatikan keluhan dan masukan dari pelanggan atau 
konsumen dan segera memperbaikinya. Selain itu, lebih meningkatkan pelayanan yang dilakukan hingga menimbulkan kepuasan dari pelanggannya.

\section{DAFTAR PUSTAKA}

Afrizal, D. (2020). E- government service review in Dumai City Indonesia : (conceptual paper). Jurnal Niara, 13(1), 260-267.

Afrizal, D., \& Sahuri, C. (2012). Analisis manajemen pelayanan publik. Jurnal Administrasi Pembangunan, 1(1), 47-50.

Andika, A., \& Susanti, F. (2018). Pengaruh marketing mix terhadap keputusan pembelian parfum di Azzwars Parfum Lubeg Padang. 1-13. https://doi.org/10.31227/osf.io/upgc3

Aryandi, J., \& Onsardi. (2020). Pengaruh kualitas pelayanan dan lokasi terhadap keputusan pembelian konsumen pada Cafe Wareg Bengkulu. Jurnal Manajemen Modal Insani Dan Bisnis, 1(1), 127.

Badriyah, N., Wibowo, E., \& Sumaryanto. (2020). Meningkatkan loyalitas pelanggan dengan kekuatan kualitas produk dan kualitas pelayanan melalui kepuasan pelanggan (survei pada pelanggan JCO Chinesefood And Seafood Sragen. Pro Bank: Jurnal Ekonomi Dan Perbankan, 5(2), 227-240.

Bakti, U., Hairudin, \& Alie, M. S. (2020). Pengaruh kualitas pelayanan, produk dan harga terhadap minat beli pada toko online Lazada di Bandar Lampung. Jurnal Ekonomi, 22(1), 101-118. https://mediakonsumen.com/2018/05/14/sur

Efendi, B. (2020). Pengaruh experiential marketing, kepuasan pelanggan, dan citra rumah makan terhadap loyalitas pelanggan (studi empirik pada rumah makan saung mansur Banjarnegara). Journal of Economic, Management, Accounting and Technology, 3(2), 161-168. https://doi.org/10.32500/jematech.v3i2.1335

Jonathan, S. (2006). Metode penelitian kuantitatif \& kualitatif (edisi pert). Graha Ilmu.

Nuristiqomah, S., Widodo, J., \& Zulianto, M. (2020). Pengaruh kualitas produk terhadap kepuasan konsumen kartu prabayar simpati Telkomsel. Jurnal Ilmiah Ilmu Pendidikan, Ilmu Ekonomi Dan Ilmu Sosial, 14(1), 166-170.

Rahman, M. F., Yulianti, F., \& Rina. (2020). Analisis strategi harga dan kualitas produksi terhadap kepuasan konsumen pada perusahaan kue Hj. Enong Bakery di Martapura. in Fakultas Ekonomi. Universitas Islam Kalimantan.

Rasmikayati, E., Saefudin, B. R., Karyani, T., Kusno, K., \& Rizkiansyah, R. (2020). Analisis faktor dan tingkat kepuasan ditinjau dari kualitas produk dan pelayanan pada konsumen sayuran organik di Lotte Mart Kota Bandung. Mimbar Agribisnis: Jurnal Pemikiran Masyarakat Ilmiah Berwawasan Agribisnis, 6(1), 351. https://doi.org/10.25157/ma.v6i1.3219

Setiawan, A. I., Kurniaty, \& Vitria, A. (2020). Pengaruh lokasi dan harga terhadap keputusan pembelian pada rumah makan padang padi rimbun banjarbaru. Universitas Islam Kalimantan.

Shafinah, K., \& Ahmad, I. (2018). Metodologi kajian-pelbagai gaya penyelidikan (Issue August 2018). Venton Publishing (M) SDN. BHD. https://www.researchgate.net/ publication/331221670_Analisis_Data_Kuantitatif_Kenapa_PLS-SEM/stats

Zuliarni, S., \& Hidayat, R. T. (2013). Analisis faktor pertimbangan pebisnis restoran kelas kecil di Lingkungan Kampus Universitas Riau Dalam Pemilihan Lokasi Usah. Jurnal Aplikasi Bisnis, 3(2), 100-119. 